\title{
The Role of Media Device in Spreading the Legal Culture in Society
}

\author{
Najwa Abu Haiba \& Soad Matar
}

\begin{abstract}
This research discusses a very important matter nowadays, which is "the society culture", because the more lawfully, environmentally, healthy, economically cultured the society be, the more able it's to defense itself from the outside attacks that aims at destroying that society. The society is always cultured; awared when it has a responsible media device, where the mission of spreading the lawful awareness falls upon the media, which is the tenor of the famous rule "the inadmissibility to apologize for the ignorance of the law after its promulgation" the person can't be asked for his acts unless it's spreaded and known. Consequently, the average of crimes and contraventions decreases, and that was the role duty of the media bodies that aims at spreading culture for all people regardless of their educational degree, because it reaches people through the visual, audio, and printed media. But however the freedom of opinion expression width goes, it's still limited with the state's laws. The modern way requires the discussion methodology when media device plays it's role in transferring society wishes to the government.

The aim of this research is calling for the supporting of media device to guarantee a cultured, fortified society.
\end{abstract}

Keywords - Media-Culture-The laws -Responsibility-Freedom of opinion expression-awareness.

\section{INT RODUCT ION}

$\mathrm{W}$ ITH the increasing of problems and issues which face our societies today, Not a little number of people exist between us, who are unaware of what is going on around them of events, thus they do not interact with it, not because of the lack of sense or ignoring these events, but because of failing to understand the content and objectives of these events, this lack needs for what is known as cultural awareness for everything that goes on around us from events, culture and knowledge of the rights and obligations that everyone must know them, for them to understand and be aware of the simplest transactions that interact in their normal life, (Bakr, 2012); in addition to the importance of recognizing the content of human rights, this vital task in fact rests with officials, media and elite in general, so that it is intended to increase cultural awareness in general and the legal one in particular, to take a call under the name of "national strategic initiative to raise

Al Ain University of Science and Technology - UAE. awareness of the legal culture in the Arab countries".

The last period experienced by many countries in the world have shown that there is an urgent need for a comprehensive plan to increase the cultural, intellectual and media awareness, which must be based on clarity and transparency and credibility of consciousness. For example, if we took the initiative to ask anyone on the difference of his location or age about what for him (from rights) and what on him (from obligations), we may be shocked about their simple or compound ignorance of their rights and duties, and we will see them based on his personal efforts and his individually vision that did not rely on grows scientific material, accordingly, the natural corollary of these interpretations we will see them different from one person to another.

Our society is in a real need for this national strategy of legal culture, and in this paper we demand media device to take over this national mission (Mohammed Abdullah, 2008), which is in fact considered the most important and most comprehensive types of awareness, and in the forefront of it is the social awareness, which means citizen's absorbing for everything that revolves around from relationships, concepts, and events, through the proper legal understanding, leading him to respect the law and its rules, so that he deals with the duties or obligations incumbent upon him as something found in his favor at present and in the future for his children, and therefore is not intended to harm him.

This degree of awareness and the good understanding of the responsibilities will not be gotten except through the conviction of the importance and the need for a law in the person's life, and that this law can't be divided from the personal responsibility, and it's an indisputable national and a moral duty, and the person must comply with its provisions, or otherwise, will be punished. Bearing in mind that the publication of the legal culture (or awareness of the law) is not just the knowledge of legislation and legal texts (Khalid, 2015), it also does not mean that theoretical discussion and legal seminars, which are made among the specialized jurists, professors and scholars, judges, lawyers and other jurists, prosecutors and the judiciary, which often look beyond the immediate concerns of the citizen.

This research aims to push the media devices into taking wide initiative in spreading the culture of awareness of the law to all classes and ages of citizens specially the non-specialists in the law, and that in itself will establish permanent 
communication channels between those concerned with the development of a culture of awareness of the law (Tamar, 2010), whether at the local level, or the regional and international level, which create a real effectiveness and dynamism of this national strategy for legal culture.

It is recognized by the rules that being aware of the law is the normal expected position, and no excuse nor an argument for the ignorance of the law, this rule is considered a legal conclusive presumption unable to prove its opposite in the judicial applications, in other words, people are supposed to know any law newly issued or amended after its publication in the Official Gazette (Lubna, 2010), and it's not accepted from anyone to apologize for his ignorance of the law, and its provisions, so, do all the members of the community know what do laws contain from texts and provisions that govern their lives (Henry, 2001) specially those laws which are treated with its provisions largely, as the law of penalties and civil law and civil contracts such as contract of sale and rent, insurance and social security law, corporate law, transactions commercial law, labor law and others, and does everyone watch and read the official Gazette and what it contains of the various legal topics?

The answer to these questions will be negative. The only guaranteed way to resolve this problem, will be by publishing the culture of the legal awareness and working on delivering legal information to all segments of society so that they can see what laws and regulations do govern them and regulate their transactions and protects their interests. Some of the most important methods to deliver legal information to individuals, aware them and spread the legal culture are the different media devices, specially the written media, which is the ideal method to communicate with the members of the local community, to deliver the news and information to individuals at all their levels.

The written media is specialized from the other methods of communication with the high credibility, because the printed word has its own charm, which affects the reader (Bakr, 2012), besides that it's a physical body that can be kept and read several times and can re-retrieval information from it, unlike the other methods, like the television and radio.

Spreading the culture of law and giving it the suitable position for it in the daily newspapers and weekly magazines, newsletters and websites pages, falls on the responsibility of who are responsible about it, and we wait the day when we read between the pages of a newspaper, and in a separate page entitled legal topics on the table, or legal opinions on an issue of interest to the citizen, or awareness legal article of legal problem encountered by the citizen in his dealings with official institution or with natural or legal persons, or a statement of opinion of law in transactions or legal relationship happens frequently between members of the community (Mohamed Abdul Salam, 2016), or other legal issues, the ignorance became inside it as a big loophole, black hole in the social and cultural local evolution.

\section{A. The General Theory Of The Contract}

Elements of the contract: this theory deals with the formation of a contract and consequent obligations, the existence of the contract requires the existence of its basic pillars (consensual - material - the reason), and if any of these elements was missed, the contract will be nulled and voided, and this is of a great importance to the members who deal with contracts. (Such as sales and lease contracts) Certainly, many of them do not know needed legal rules to create contracts. And here comes the role of the media and its different methods in spreading the culture of creating contracts as required by the law.

\section{B. Will Defects}

It's required for the validity of the contract or any legal act, a settlement to be done between the parties to the contract and that they own the full capacity, and that the issue sounds nondefective, If the will of any of them got defected by any defect of the will defects (Mistake - Fraud - coercion) the contract will be faulted, which puts it in the position of invalidity in favor of the party that took place in mistake or under duress. For contracts to come valid from people who do not have sufficient knowledge of the creation of contracts, it is necessary to give them the ways and means to know their rights and obligations (Abdul Razzaq, 1974), and this is the visual and written media role.

\section{Civil responsibility}

CLC include two types: contractual liability and tort responsibility, the contractual liability arises when one party fails to fulfill one of the obligations arising from the contract, that was concluded with the other party, in the other hand, the tort responsibility arises at the occurrence of an error or adverse reaction from someone who causes the harm to others (Abdul Razzaq, 1974), consequently, the first be obliged for compensating to the injured person, even though the one that was in charge of the compensation is indiscriminate (minor), and in here the tort differ from contractual liability. All of these things on large degree of importance needs to acknowledged and known, and this is the task (role) of the media.

\section{Foreclosure}

Mortgage is divided into two types, mortgage insurance and mortgage possessory and both are contracts the show the mortgager (which may be a debtor or guarantor eye) and the mortgagee, and the goal of the mortgage is guarantee creditor's rights in obtaining his right of the mortgaged thing when sold at auction if the debtor has not payed back the debt at the deadline.

And young people deal with a mortgage when someone aims at buy a car or a house through the bank, and mortgaging a thing (car or home) to ensure repayment (fulfilling), and the buyer may not be able to pay back (debtor), which may be 
exposed car or home for sale (Jamil, 1977). And so that no one falls in these problems, it's needed to be aware of all the consequences of foreclosure. This is also a task of the local media.

\section{E. Creating companies}

There are many types of companies, including funds companies and persons corporate, and each of them have their shape and conditions of its creation (Mohamed Ahmed, 2015), and here is the role of the media in showing the establishment of all the companies.

\section{Mechanisms Of SpREADING ThE CUlture OF AWARENESS OF THE LAW}

Mechanisms of spreading the culture of awareness of the law Diversified and integrated to achieve these expected noble goals from the sovereignty of the culture of awareness of the law, by understanding, by knowledge, scientifically, practically, by behavior, application and a role model and motivating others, and these mechanisms are:

\section{A. First}

Education institutions: The role of education institutions is considered central to the development of a culture of awareness of the law, due to the link between the education period and the creation stage, personal growth, maturity and awareness, and then, education institutions must perform its duty in the development of the culture of awareness of the law through the teaching of the legal culture in the various stages of education and to be ranged in its content according to the age stage (Tamar, 2010), so that culture is completed with the student's graduation and earning his degree

\section{B. Second}

Cultural institutions: habits, values and behaviors of community members are usually formed, through those cultural institutions, which are deployed in the villages and towns, as well as those institutions and central sectors of the mother capital (Jack, 2014), and can point to a number of scientific mechanisms for the publication of the legal culture, including: organizing convoys and campaigns to educate law through the Cultural Palaces, which university professors, judges, parliamentarians and lawyers participate in it, to simplify the general legal concepts, and conduct dialogues with citizens to correct misconceptions, and to respond to their questions and inquiries about the legal terms that may be confusing to them, and make it clear to them, and work on consolidate the idea of citizenship they have, and to clarify the concepts of the Constitution and the law to them, and prepare awareness booklets simplified to facilitate understanding of the ABCs of law which is called the gateway to the study of law dealing with the theory of justice and the theory of law and the branches of law and the relationship of law to other sciences and the importance of law in society and others.

\section{Third}

Media device: the role of the media in developing a culture of awareness of the law is a central and active role, whether written (newspapers and magazines) or television or radio or electronic (on internet), as those methods are the eyes of the masses and tongue, and its prompt collective mind and a public culture organizer to spread those methods and reach the intensive audiences, and its continuously and urgency insist all the time (Saleh, 2016), in addition to its public discourse that reaches a large number of disparate humans, that some of them suffering from the low culture, illiteracy and ignorance, and then it must play its full part in the development of a culture of awareness of the law.

\section{Fourth}

The courts: courts have different types and degrees of responsibility for adjudicating disputes and deductions before it, after a fair, impartial and transparent trial proceedings, it must take into account the procedural legitimacy and that people see justice when it is realized, because the basic rule was the public hearings, and then can identify the most important axes of the courts role in the legal culture in organizing legal forums cultural in the role of the criminal courts, civil or administrative, constitutional or military, in the informal working time to different groups of people, lectured by the judges themselves, and support the courts by technological devices for the possibility for the litigants to follow-up their cases via the Internet in order to avoid to bother traveling to the headquarters of the courts and what they suffered from hardships (Jack, 2014), and the traffic of streets and roads, and the possibility of the electronic trials search in the disputes that aren't criminal which requires habeas corpus, and to provide evidence of a judicial paper or electronic litigation to explain the procedures for citizens.

\section{E. Fifth}

International and regional organizations: those organizations can play an important role in the development of culture of awareness of the law through a number of mechanisms, including the strengthening of plans and programs for the work of these organizations in order to raise the level of awareness and legal culture, and create a data bank legal Email with the task of spreading the culture of awareness of the law of the various categories and ages of society, and social networking with those organizations, and to promote communication between international and regional organizations with national civil society organizations to achieve common goals for the development of a culture of awareness of the law.

\section{CONCLUSiON}

It can be concluded that the Journalism has an important enlightening role in informing the community members the importance of law and the need to apply it and be bound by it, and telling them their rights and duties and developing the 
human rights awareness of the civil society and addressing human rights issues and awareness of political, civil, economic and cultural rights, and the consolidation of democratic awareness, and monitoring of the nests of corruption and the failure, to reach a serious treatments for the aspects of the default, in transparency and objectivity, by provoking a legal motion and promote civil rights issues to create a civil society that understands the rights and competences and duties.

Although the existence of the important role of the media device, When we read the daily and weekly newspapers and turn its pages, we find addresses and different topics for pages, as the economic, cultural, and sports pages and others (Saleh, 2016). But unfortunately we do not find a specialized legal page dedicated to the publication of legal culture among members of the community, knowing that the law is regulating the work of the newspapers and the media, the law of prints and publication, And the law of the Higher Media Council and the law of guaranteeing the right of access to information, Is not this a negligence against the law?

It's also noticed that the written media, which is formed in the daily newspapers, weekly magazines and others, and goes by commenting and talking to the different sectors of social, commercial, political, cultural and artistic life, But through a closer look at the contents of their pages we note that it distanced itself from giving the law the right that it deserves to exist between the folds of its pages.

It's the right time for the heading of the written media on specializing legal Page between the various folds of its pages will be considered a positive and healthy phenomenon ( Hassan, 2014), and will give a distinct impression to this page and increase the number of newspaper readers, because the rule of law and justice are the basis of the creation of any civilized society in addition to its urgent necessity to organize all aspects of life, and governs all individual and corporate transactions, unlike the other pages that may not be of the interest to only a certain class or sector of people.

\section{RECOMMENDATIONS}

1. Spreading a culture of respecting the law among the community is divided into two phases: the first over the child at the school by teaching him the respect for the law, through curriculum development and add a simple legal texts explain to the children how to respect the law and its application. The second phase which is about raising the child properly by his family, and upbringing him on respecting others, and the need for applying the law and not committing violations such as libel and defamation traffic contraventions and the other illegal acts.

2. Create a private channel for child protection laws.

3. Strengthening the role of the media in spreading the culture of law.

.Respect the laws of the countries visited by the citizens. 4

. .To stand against the rumors by social media 5

6. Activate the parents meetings in school to solve problems of the students.
.Impose a fine on a parent deliberates not to attend the Parents meeting.7

Clarify the laws and explain it in a simple way to the community members. 8

9. Teach students legal texts related to their everyday life.

10. Cooperation «internal ministry» and «Education ministry» to organize awareness campaigns for students.

11. Promote the values and behavior rectum, laws and legislation in the hearts and minds of students

12. Strengthening the role of the family in inculcating a culture of respect for the law among children, as the nucleus of the children, which is the first source to receive the information and broadcasting in the hearts of children.

13. Activating the role of educational institutions in promoting the values and behavior rectum.

14. Study and control of some satellite channels that contribute to the spread of crime content.

15. Establish the principle of respect for the law out of conviction and not out of fear.

15

16. Establish balanced positive relationship between students' parents and the school

17.Inculcate positive values among students and push them to comply with ethics laws 17

18. Finally, taking into account the focus on four themes, namely: a culture of respect for the law and its importance from social, religious and legal aspects, the role of educational institutions in inculcating a culture of respecting the law, and social networking sites and their impact on young people

On the other hand, media device should observe that there are a number of legal organizing provisions that aim to support the creative and educational manufacturing and industries, for example, the television, featuring films, video, songs, weekly magazines and daily newspapers. There are also legal systems encouraging actors', authors', composers', musicians' and various artists' collectives, all these sectors have legal importance for many society members, and they must be aware of them, and this is the role of media

Taking into account, that RIGHTS AND FREEDOMS acknowledged "freedom of thought, belief, opinion, and expression, including freedom of the press and other media of communication" as one of the basic freedom rules in the constitution.

Because the freedom has always been recognized as "freedom governed by law, "the fundamental freedoms under the Charter are subject to "such reasonable limits prescribed by law as can be demonstrably justified in a free and democratic society." Lately, Limitations came in various types. Some of them apply to all media devices, others apply to specific media devices, and others to people that communicate through their own way.

For instance, The law of defamation is the basic limit on the unfettered speech, where the civil law is applied, if there is one person writes or records and spreads a message that insults or disrespect another person or in the society, then the former must prepare to the court, using proper evidences, to prove that the message, record, the written thing is not true. 
Manifestation the opinions can be guaranteed, as the equitable opinion on a matter of the public interest.

\section{REFERENCES}

[1] Abdul Razzaq Sanhouri, contract theory, 1974

[2] Bakr Abdel-Fattah Al-Sarhan, legal culture, Dar march 0.2012.

[3] Hassan Hassan Lahdan Muhannadi, a society conscious about their rights and duties, legal awareness 0.2014 .

[4] Henry Jenkins, “Convergence? I Diverge," Technology Review, June 2001, p. 93

[5] Jack Lule, Understanding Media and Culture: An Introduction to Mass Communication, March 2014, p.4

[6] Jamil al-Sharqawi, sources Commitment, 1977

[7] Khalid Ahmed Al-Muhammadi, a digital integrated legal community, Libra magazine 0.2015 .

[8] Lubna Immortalized Adaileh, legal culture, a study in the Jordanian penal code, 2010

[9] Mohamed Abdul Salam Ahmed, a political media, Dar university education, Alexandria 2016.

[10] Mohamed Ahmed Mohamed Ali, the Western media and the problems of Islam-freedom, Sultan Bin Zayed Centre. 2015.

[11] Mohammed Abdullah al-Sahli, the means of spreading the culture of rights and duties, Riyadh, regulations and law in 2008.

[12] Saleh Bakr pilot, the legal culture and education curricula 0.2016 .

[13] Tamar Lewin, "If Your Kids Are Awake, They're Probably Online," The New York Times, Education section, January 20, 2010, http://www.nytimes.com/2010/01/20/education/20wired.html (accessed July 15, 2010). 